\title{
Electron Microscopy Study of Eutectic Structure in Nb-Ti-X and Nb-Zr-X (X = Co, Ni) Hydrogen Permeation Alloys
}

\author{
Mitsuhiro Matsuda ${ }^{1}$, Takuya Murasaki ${ }^{1}$, Minoru Nishida ${ }^{2}$, Kazuhiro Ishikawa ${ }^{3}$ and Kiyoshi Aoki ${ }^{3}$ \\ ${ }^{1}$ Department of Materials Science and Engineering, Kumamoto University, Kumamoto 860-8555, Japan \\ ${ }^{2}$ Department of Applied Science for Electronics and Materials, Kyushu University, Kasuga 816-8580, Japan \\ ${ }^{3}$ Department of Materials Science, Kitami Institute of Technology, Kitami 090-8507, Japan
}

\begin{abstract}
The morphology and crystallography of eutectic structures in several niobium-bearing hydrogen permeation alloys such as $\mathrm{Nb}_{20} \mathrm{Ti}_{40} \mathrm{Ni}_{40}$, $\mathrm{Nb}_{30} \mathrm{Ti}_{35} \mathrm{Co}_{35}, \mathrm{Nb}_{13} \mathrm{Zr}_{43} \mathrm{Ni}_{44}$, and $\mathrm{Nb}_{25} \mathrm{Zr}_{35} \mathrm{Co}_{40}$ have been investigated by means of transmission electron microscopy. The alloys $\mathrm{Nb}_{20} \mathrm{Ti}_{40} \mathrm{Ni}_{40}, \mathrm{Nb}_{30} \mathrm{Ti}_{35} \mathrm{Co}_{35}$, and $\mathrm{Nb}_{25} \mathrm{Zr}_{35} \mathrm{Co}_{40}$ possess eutectic structures consisting of fine lamellar morphology with $\mathrm{Nb}-$ based bcc and $\mathrm{B} 2$ intermetallic phases. The $\mathrm{Nb}_{13} \mathrm{Zr}_{43} \mathrm{Ni}_{44}$ alloy possesses a eutectic structure consisting of rod-shaped bcc-(Nb, Zr) phase and B33-ZrNi phase which displacively transforms from the B2 high-temperature phase. The eutectic structures in the $\mathrm{Nb}_{20} \mathrm{Ti}_{40} \mathrm{Ni}_{40}$ and the $\mathrm{Nb}_{25} \mathrm{Zr}_{35} \mathrm{Co}_{40}$ alloys exhibit a cube-on-cube orientation relationship between the bcc and B2 phases. The eutectic structure in the $\mathrm{Nb}_{13} \mathrm{Zr}_{43} \mathrm{Ni}_{44}$ alloy also exhibits a cube-on-cube orientation relationship by considering the lattice correspondence between the B2 and the B33 structures. On the other hand, a unique orientation relationship is found out in the $\mathrm{Nb}_{30} \mathrm{Ti}_{35} \mathrm{Co}_{35}$ alloy, as follows: (110) $(\mathrm{Nb}, \mathrm{Ti}) / /(110)_{\mathrm{TiCo}},[\overline{2} 21]_{(\mathrm{Nb}, \mathrm{Ti})} / /[001]_{\mathrm{TiCo}}$. The atomic arrangements at the eutectic interface are also discussed on the basis of high-resolution observations. [doi:10.2320/matertrans.MA200803]
\end{abstract}

(Received April 23, 2008; Accepted May 20, 2008; Published July 2, 2008)

Keywords: eutectic structure, niobium-bearing alloy, transmission electron microscopy, orientation relationship

\section{Introduction}

Pd-Ag alloys have been commercially used as hydrogen permeation membranes for separating and purifying hydrogen gas. Since $\mathrm{Pd}$ is too expensive and scarce in resources, it is desirable to develop non-Pd-based hydrogen permeation alloys with low cost and high performance. From the viewpoint of the hydrogen permeability for this demand, group 5A metals such as $\mathrm{V}, \mathrm{Nb}$, and $\mathrm{Ta}$ are promising candidates, because the hydrogen permeability of such metals is higher than those of Pd and Pd-Ag alloys. ${ }^{1-3)}$ However, since these metals suffer from severe hydrogen embrittlement, they cannot be used as membranes at present. Recently, one of the authors found out that the Nb-Ti-Ni alloy consists of bcc-(Nb, Ti) + B2-TiNi eutectic microstructures with an appropriate combination of high-hydrogen permeability and excellent hydrogen embrittlement resistance. ${ }^{4,5)}$ The former property is attributable to the bcc$(\mathrm{Nb}, \mathrm{Ti})$ phase, while the latter property is attributable to the B2-TiNi phase in the eutectic structure. On the basis of the same concept, $\mathrm{Nb}-\mathrm{Ti}-\mathrm{Co},{ }^{6)} \mathrm{Nb}-\mathrm{Zr}-\mathrm{Ni}^{7,8)}$ and $\mathrm{Nb}-\mathrm{Zr}-\mathrm{Co}$ alloys have been developed as new hydrogen permeation materials. In these alloys, the eutectic structure is considered to be valuable and indispensable in achieving the compatible properties. However, no study has yet focused on such eutectic microstructures, except for the $\mathrm{Nb}_{20} \mathrm{Ti}_{40} \mathrm{Ni}_{40}$ alloy. 9,10$)$

The purpose of this paper is to clarify the morphology and crystallography of the eutectic structures in the four types of the $\mathrm{Nb}$-bearing hydrogen permeation alloys, i.e., $\mathrm{Nb}_{20} \mathrm{Ti}_{40} \mathrm{Ni}_{40}, \quad \mathrm{Nb}_{30} \mathrm{Ti}_{35} \mathrm{Co}_{35}, \mathrm{Nb}_{13} \mathrm{Zr}_{43} \mathrm{Ni}_{44}$, and $\mathrm{Nb}_{25}-$ $\mathrm{Zr}_{35} \mathrm{Co}_{40}$ by means of conventional transmission electron microscopy (CTEM). The atomic arrangements at the eutectic interface are also discussed on the basis of highresolution transmission electron microscopy (HRTEM) observations.

\section{Experimental Procedure}

The eutectic alloys $\mathrm{Nb}_{20} \mathrm{Ti}_{40} \mathrm{Ni}_{40}, \mathrm{Nb}_{30} \mathrm{Ti}_{35} \mathrm{Co}_{35}, \mathrm{Nb}_{13}$ $\mathrm{Zr}_{43} \mathrm{Ni}_{44}$, and $\mathrm{Nb}_{25} \mathrm{Zr}_{35} \mathrm{Co}_{40}$ (at\%) were prepared from 99.9\% $\mathrm{Nb}, 99.7 \% \mathrm{Ti}, 99.9 \% \mathrm{Ni}, 99.9 \% \mathrm{Co}$, and $99.9 \% \mathrm{Zr}$ (\% by mass) by arc melting in an argon atmosphere. The structural and microstructural examinations were carried out by using a X-ray diffractometer (XRD) and a scanning electron microscope (SEM), respectively. The TEM specimens were cut from the as-melted ingots and prepared by the argon ion milling technique. The CTEM and HRTEM observations were performed by using JEM-2000FX and FEI-Tecnai20F microscopes operated at $200 \mathrm{kV}$, respectively.

\section{Results and Discussion}

Figure 1 shows the XRD patterns of the four eutectic alloys. The $\mathrm{Nb}_{20} \mathrm{Ti}_{40} \mathrm{Ni}_{40}$ alloy consists of the bcc-(Nb, Ti) solid solution and B2-TiNi phase, ${ }^{4)}$ as shown in Fig. 1(a). The lattice parameters of the $(\mathrm{Nb}, \mathrm{Ti})$ solid solution and Ti-Ni phase are calculated to be $0.329 \mathrm{~nm}$ and $0.302 \mathrm{~nm}$, respectively. Although a near-equiatomic Ti-Ni alloy undergoes a thermoelastic martensitic transformation from the B2 to B19' structure at approximately $373 \mathrm{~K}$ upon cooling, ${ }^{11)}$ the TiNi phase in the eutectic $\mathrm{Nb}_{20} \mathrm{Ti}_{40} \mathrm{Ni}_{40}$ alloy possesses the B2 structure, as shown in Fig. 1(a). This occurs because the Ms point of the TiNi phase decreases below room temperature by the dissolution of a small amount of $\mathrm{Nb}$ in the Ti-Ni phase. ${ }^{12)}$ Similarly, the $\mathrm{Nb}_{30} \mathrm{Ti}_{35} \mathrm{Co}_{35}$ alloy consists of the bcc-(Nb, Ti) solid solution and B2-TiCo phase, $\left.{ }^{6}\right)$ as shown in Fig. 1(b). The lattice parameters of the (Nb, Ti) solid solution and TiCo phase are estimated to be $0.331 \mathrm{~nm}$ and $0.301 \mathrm{~nm}$, respectively. The $\mathrm{Nb}_{13} \mathrm{Zr}_{43} \mathrm{Ni}_{44}$ alloy is composed of the bcc-( $\mathrm{Nb}, \mathrm{Zr})$ solid solution and $\mathrm{B} 33-\mathrm{ZrNi}$ phase with an orthorhombic cell, ${ }^{7,13)}$ as shown in Fig. 1(c). 


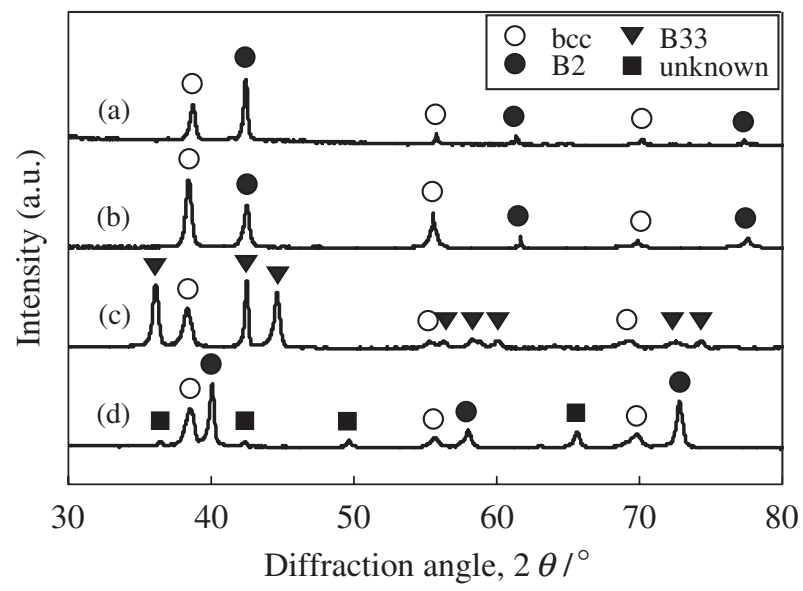

Fig. 1 XRD patterns of the (a) $\mathrm{Nb}_{20} \mathrm{Ti}_{40} \mathrm{Ni}_{40}$, (b) $\mathrm{Nb}_{30} \mathrm{Ti}_{35} \mathrm{Co}_{35}$, (c) $\mathrm{Nb}_{13} \mathrm{Zr}_{43} \mathrm{Ni}_{44}$, and (d) $\mathrm{Nb}_{25} \mathrm{Zr}_{35} \mathrm{Co}_{40}$ eutectic alloys.
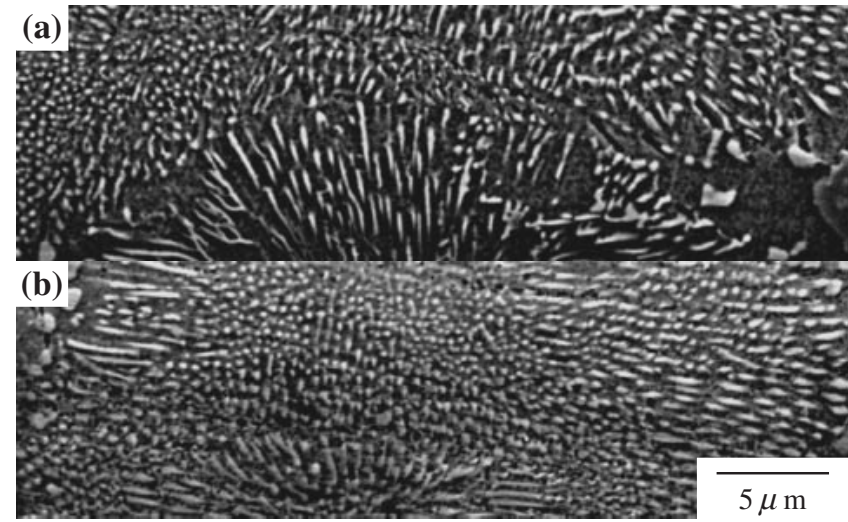

Fig. 3 SEM images of the (a) longitudinal and (b) vertical section of the same part in the $\mathrm{Nb}_{13} \mathrm{Zr}_{43} \mathrm{Ni}_{44}$ ingot, showing the rod-shaped structure.
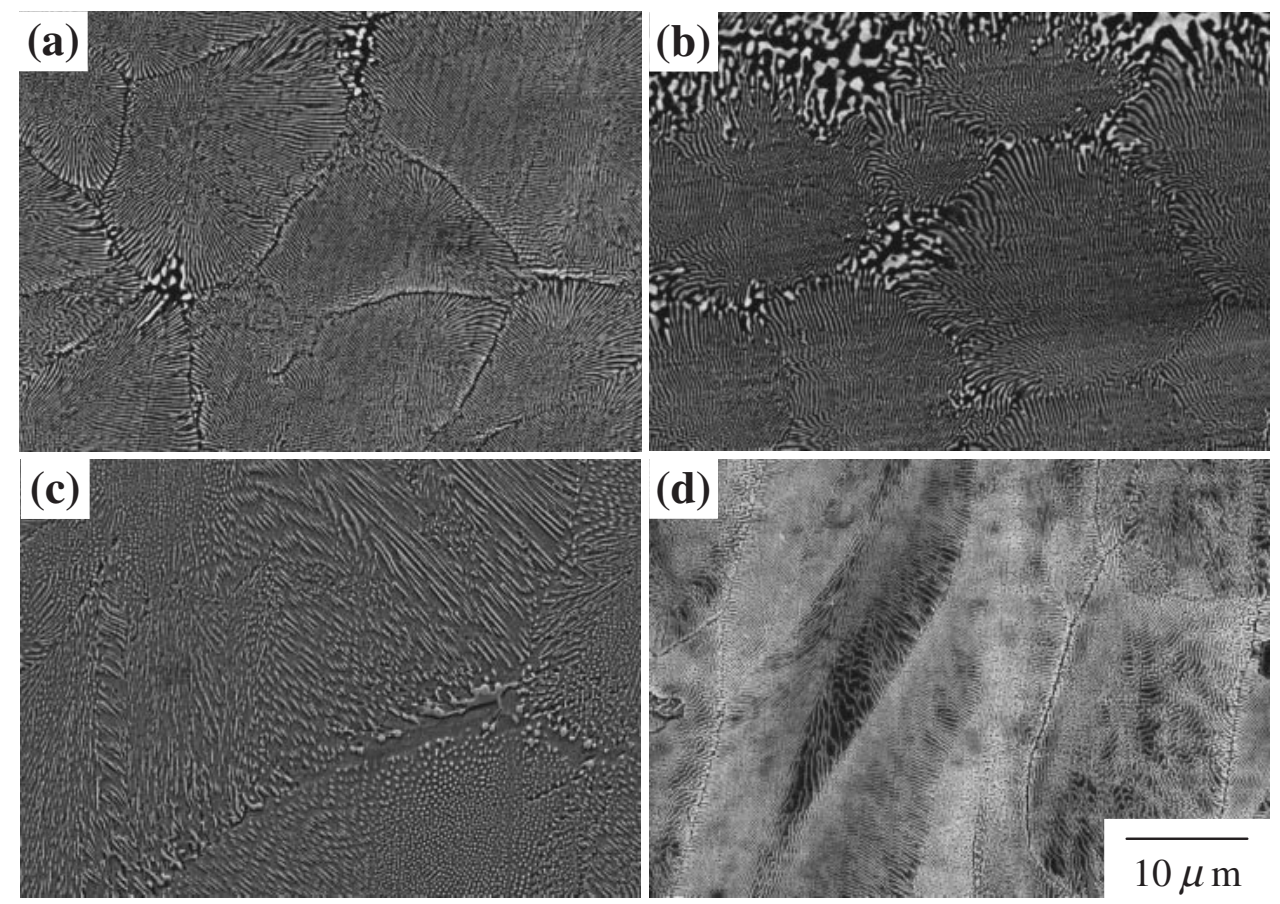

Fig. 2 SEM images of the (a) $\mathrm{Nb}_{20} \mathrm{Ti}_{40} \mathrm{Ni}_{40}$, (b) $\mathrm{Nb}_{30} \mathrm{Ti}_{35} \mathrm{Co}_{35}$, (c) $\mathrm{Nb}_{13} \mathrm{Zr}_{43} \mathrm{Ni}_{44}$, and (d) $\mathrm{Nb}_{25} \mathrm{Zr}_{35} \mathrm{Co}_{40}$ eutectic alloys.

The lattice parameters of the $(\mathrm{Nb}, \mathrm{Zr})$ solid solution and B-33 ZrNi phase are calculated to be $a_{(\mathrm{Nb}, \mathrm{Zr})}=0.332 \mathrm{~nm}$ and $a_{\mathrm{ZrNi}}=0.329 \mathrm{~nm}, b_{\mathrm{ZrNi}}=0.998 \mathrm{~nm} \quad c_{\mathrm{ZrNi}}=0.406 \mathrm{~nm}$, respectively. The Bragg peaks on the $\mathrm{Nb}_{25} \mathrm{Zr}_{35} \mathrm{Co}_{40}$ alloy are indexed on the basis of the bcc-( $\mathrm{Nb}, \mathrm{Zr})$ solid solution and B2-ZrCo phase, except for the unknown Bragg peaks, as shown in Fig. 1(d). The lattice parameters of the $(\mathrm{Nb}, \mathrm{Zr})$ solid solution and $\mathrm{ZrCo}$ phase are estimated to be $0.332 \mathrm{~nm}$ and $0.319 \mathrm{~nm}$, respectively.

In order to investigate the microstructure of each eutectic alloy, SEM observations are carried out as shown in Fig. 2. The $\mathrm{Nb}_{20} \mathrm{Ti}_{40} \mathrm{Ni}_{40}, \mathrm{Nb}_{30} \mathrm{Ti}_{35} \mathrm{Co}_{35}$, and $\mathrm{Nb}_{25} \mathrm{Zr}_{35} \mathrm{Co}_{40}$ alloys possess eutectic structures with a fine lamellar morphology, as shown in Figs. 2(a), 2(b), and 2(d), respectively. The $\mathrm{Nb}_{13} \mathrm{Zr}_{43} \mathrm{Ni}_{44}$ alloy possesses a eutectic structure with lamellar and granular morphologies, as shown in Fig. 2(c). To clarify the morphology of such eutectic structures, SEM observations of the longitudinal and vertical sections of the same part in the $\mathrm{Nb}_{13} \mathrm{Zr}_{43} \mathrm{Ni}_{44}$ ingot are performed, as shown in Figs. 3(a) and 3(b). It is apparent that the $\mathrm{Nb}_{13} \mathrm{Zr}_{43} \mathrm{Ni}_{44}$ alloy consists of a rod-shaped structure. The results obtained from the XRD and SEM observations are summarized in Table 1. It has been recognized that the eutectic structure possesses a lamellar morphology when the volume fraction of the second phase is greater than $28 \%$. While the rodshaped morphology is observed for volume fractions less than $28 \% .{ }^{14)}$ Here, the volume fraction of the Nb-based bcc phase in the $\mathrm{Nb}_{20} \mathrm{Ti}_{40} \mathrm{Ni}_{40}, \mathrm{Nb}_{30} \mathrm{Ti}_{35} \mathrm{Co}_{35}$, and $\mathrm{Nb}_{25} \mathrm{Zr}_{35} \mathrm{Co}_{40}$ alloys are $33.3,32.3$, and $34.2 \%$, respectively, as listed in Table 1. On the other hand, the volume fraction of the $(\mathrm{Nb}$, $\mathrm{Zr}$ ) solid solution in the $\mathrm{Nb}_{13} \mathrm{Zr}_{43} \mathrm{Ni}_{44}$ alloy is $21.9 \%$. Therefore, the $\mathrm{Nb}_{13} \mathrm{Zr}_{43} \mathrm{Ni}_{44}$ alloy consists of the rod-shaped eutectic structure, as apparent from the abovementioned criteria. 
Table 1 Characteristics of the eutectic structure in the four niobium-bearing alloys.

\begin{tabular}{|c|c|c|c|c|}
\hline & $\mathrm{Nb}_{20} \mathrm{Ti}_{40} \mathrm{Ni}_{40}$ & $\mathrm{Nb}_{30} \mathrm{Ti}_{35} \mathrm{Co}_{35}$ & $\mathrm{Nb}_{13} \mathrm{Zr}_{43} \mathrm{Ni}_{44}$ & $\mathrm{Nb}_{25} \mathrm{Zr}_{35} \mathrm{Co}_{40}$ \\
\hline Morphology & lamellar & lamellar & $\operatorname{rod}$ & lamellar \\
\hline Nb-based phase & bcc- $(\mathrm{Nb}, \mathrm{Ti})$ & bcc-(Nb, Ti) & bcc- $(\mathrm{Nb}, \mathrm{Zr})$ & bcc-(Nb, Zr) \\
\hline lattice parameter $(\mathrm{nm})$ & $a=0.329$ & $a=0.331$ & $a=0.332$ & $a=0.332$ \\
\hline $\begin{array}{l}\text { Volume fraction of } \\
\text { Nb-based phase }(\%)\end{array}$ & 33.3 & 32.3 & 21.9 & 34.2 \\
\hline $\begin{array}{l}\text { Intermetallic phase } \\
\text { lattice parameter }(\mathrm{nm})\end{array}$ & $\begin{array}{c}\mathrm{B} 2-\mathrm{TiNi} \\
a=0.302\end{array}$ & $\begin{array}{c}\text { B2-TiCo } \\
a=0.301\end{array}$ & $\begin{array}{l}\mathrm{B} 33-\mathrm{ZrNi} \\
a=0.329 \\
b=0.998 \\
c=0.406\end{array}$ & $\begin{array}{c}\mathrm{B} 2-\mathrm{ZrCo} \\
a=0.319\end{array}$ \\
\hline
\end{tabular}
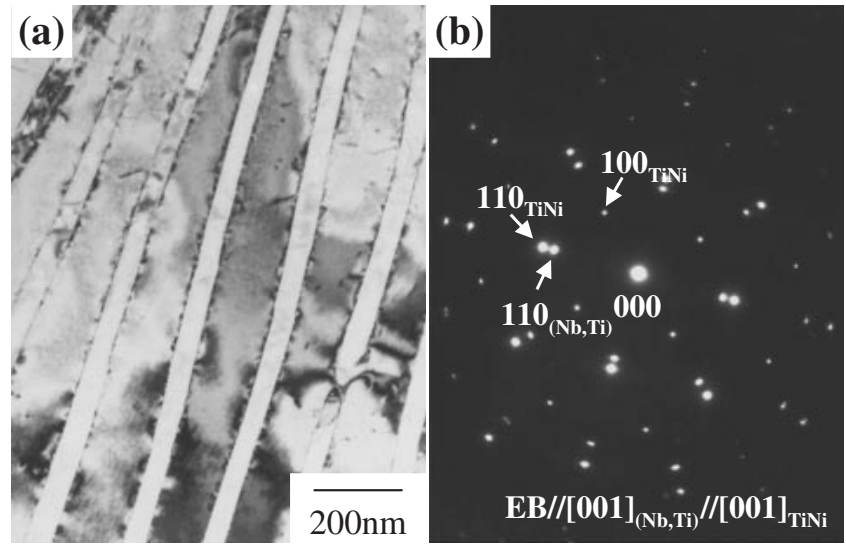

Fig. 4 (a) A bright field image and (b) the corresponding electron diffraction pattern of the $\mathrm{Nb}_{20} \mathrm{Ti}_{40} \mathrm{Ni}_{40}$ alloy from the $[001]_{(\mathrm{Nb}, \mathrm{Ti})} / /$ $[001]_{\mathrm{TiNi}}$ zone axis, showing the cube-on-cube orientation relationship.

CTEM observations are performed to clarify in detail the crystallography of the eutectic structure. Figures 4(a) and 4(b) show the typical bright field image and the corresponding electron diffraction pattern of the $\mathrm{Nb}_{20} \mathrm{Ti}_{40} \mathrm{Ni}_{40}$ alloy, respectively. From the pattern shown in Fig. 4(b) and the dark field image obtained using $100_{\mathrm{TiNi}}$ reflection, it is identified that the thicker lamellas correspond to the B2-TiNi phase, whereas the thinner lamellas correspond to the bcc$(\mathrm{Nb}, \mathrm{Ti})$ phase. The thickness of the $(\mathrm{Nb}, \mathrm{Ti})$ phase varies from 40 to $60 \mathrm{~nm}$ and that of the TiNi phase varies from 100 to $200 \mathrm{~nm}$. The orientation relationship between the $(\mathrm{Nb}, \mathrm{Ti})$ and the TiNi phases is determined as follows: $[001]_{(\mathrm{Nb}, \mathrm{Ti})} / /$ $[001]_{\mathrm{TiNi}}, \quad(100)_{(\mathrm{Nb}, \mathrm{Ti})} / /(100)_{\mathrm{TiNi}}, \quad(010)_{(\mathrm{Nb}, \mathrm{Ti})} / /(010)_{\mathrm{TiNi}}$, that is, the cube-on-cube orientation relationship is maintained between the two phases. The interface plane between the two phases is determined as $\{110\}_{(\mathrm{Nb}, \mathrm{Ti})} / /\{110\}_{\mathrm{TiNi}}$. Similar morphology and crystallography, i.e., the cube-oncube relationship between the $(\mathrm{Nb}, \mathrm{Zr})$ and the $\mathrm{ZrCo}$ phase, are confirmed for the eutectic structure of the $\mathrm{Nb}_{25} \mathrm{Zr}_{35} \mathrm{Co}_{40}$ alloy. The thickness of the $(\mathrm{Nb}, \mathrm{Zr})$ phase varies from 30 to $60 \mathrm{~nm}$ and that of the $\mathrm{ZrCo}$ phase varies from 60 to $100 \mathrm{~nm}$.

Figure 5 shows the typical bright field image and the corresponding electron diffraction patterns of the eutectic structure in the $\mathrm{Nb}_{30} \mathrm{Ti}_{35} \mathrm{Co}_{35}$ alloy. The thinner lamellas with widths ranging from 80 to $100 \mathrm{~nm}$ correspond to the bcc$(\mathrm{Nb}, \mathrm{Ti})$ phase, and the thicker lamellas with widths ranging from 150 to $200 \mathrm{~nm}$ correspond to the B2-TiCo phase. It must be noted that the orientation relationship between the the bcc-(Nb, Ti) and B2-TiCo phases is determined to be $[\overline{2} 21]_{(\mathrm{Nb}, \mathrm{Ti})} / /[001]_{\mathrm{TiCo}},(110)_{(\mathrm{Nb}, \mathrm{Ti})} / /(110)_{\mathrm{TiCo}}$. This relationship is invariant, even for specimens annealed at $1173 \mathrm{~K}$ for $360 \mathrm{ks}$. However, it is apparent that the interface is parallel to $\{110\}_{(\mathrm{Nb}, \mathrm{Ti})}$ and $\{110\}_{\mathrm{TiNi}}$, similar to that in the $\mathrm{Nb}_{20} \mathrm{Ti}_{40} \mathrm{Ni}_{40}$ alloy. This fact indicates that the two phases relatively rotate approximately $70^{\circ}$ around the common (110) plane from the cube-on-cube orientation relationship. So far as we know, this relationship is quite unique in the eutectic
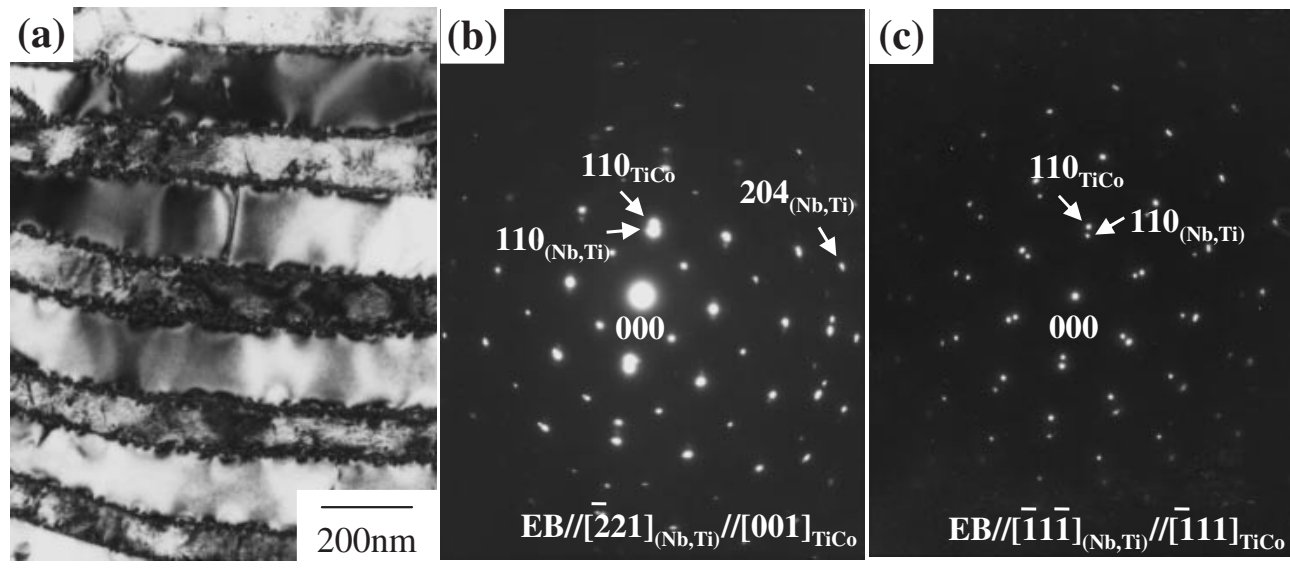

Fig. 5 (a) A bright field image, (b) and (c) the corresponding electron diffraction patterns of the $\mathrm{Nb}_{30} \mathrm{Ti}_{35} \mathrm{Co}_{35}$ alloy from the $[\overline{2} 21]_{(\mathrm{Nb}, \mathrm{Ti})} / /[001]_{\mathrm{TiNi}}$ and $[\overline{1} 1 \overline{1}]_{(\mathrm{Nb}, \mathrm{Ti}} / /\left[{ }_{1} 11\right]_{\mathrm{TiCo}}$ zone axis, respectively. 


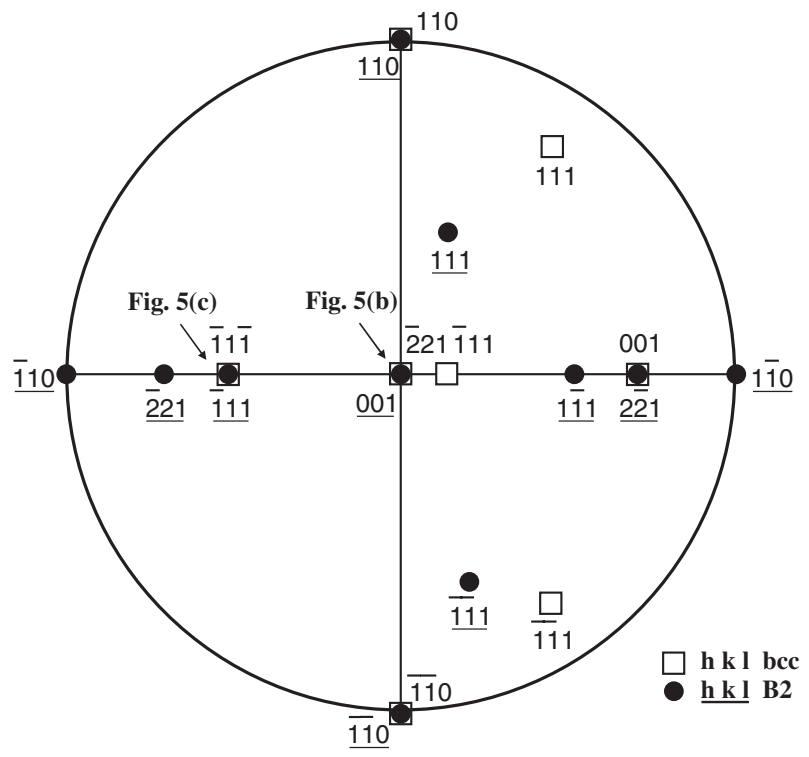

Fig. 6 Stereographic projection from the $[\overline{2} 21]_{\mathrm{bcc}}$ and $[001]_{\mathrm{B} 2}$ direction.

structure consisting of the bcc and B2 phases. ${ }^{15)}$ The strain contrast along the interface in the $\mathrm{Nb}_{30} \mathrm{Ti}_{35} \mathrm{Co}_{35}$ alloy is more complex as compared to that in the $\mathrm{Nb}_{20} \mathrm{Ti}_{40} \mathrm{Ni}_{40}$ alloy, which is probably due to the different orientation relationship. This will be discussed later in the HRTEM observations. For satisfying this orientation relationship, the direction along which the eutectic interface is observed in the edge-on state from the low index zone axis of both the phases is only $[\overline{1} 1 \overline{1}]_{(\mathrm{Nb}, \mathrm{Ti})} / /[\overline{1} 11]_{\mathrm{TiCo}}$, as shown in the stereographic projection in Fig. 6. This fact is demonstrated in Fig. 5(c).

Figure 7(a) shows the typical bright field image of the $\mathrm{Nb}_{13} \mathrm{Zr}_{43} \mathrm{Ni}_{44}$ alloy. The electron diffraction patterns in Figs. 7(b) and 7(c) are obtained from the elliptical phase A, and those in $\left(b^{\prime}\right)$ and $\left(c^{\prime}\right)$ are obtained from the matrix region B. Since the patterns (b) and (c) are consistently indexed with the bcc structure of $a_{0}=0.332 \mathrm{~nm}$ determined from the XRD experiment in Fig. 1(c), the elliptical phase A is identified as the $(\mathrm{Nb}, \mathrm{Zr})$ solid solution. The longitudinal section of the rod-like bcc phase is observed from another beam direction.
Therefore, the phase A with elliptical shape in Fig. 7(a) indicates the vertical section of the rod-like bcc phase; thus, the $[110]_{\mathrm{bcc}}$ direction is considered to be parallel to the growth direction of the rod-like phase. These observations correspond to the SEM images in Figs. 2(c) and 3. On the other hand, the patterns $\left(b^{\prime}\right)$ and $\left(c^{\prime}\right)$ can be indexed by the B33 structure with orthorhombic unit cell, as mentioned above. It is apparent from these two pairs of patterns that crystallographic orientation relationships exist between the bcc-(Nb, Zr) and B33-ZrNi phases, as follows: $(1 \overline{1} 0)_{(\mathrm{Nb}, \mathrm{Zr})} / /$ $(001)_{\mathrm{ZrNi}}, \quad(001)_{(\mathrm{Nb}, \mathrm{Zr})} / /(100)_{\mathrm{ZrNi}}, \quad(110)_{(\mathrm{Nb}, \mathrm{Zr})} / /(010)_{\mathrm{ZrNi}}$, $[110]_{(\mathrm{Nb}, \mathrm{Zr})} / /[010]_{\mathrm{ZrNi}}$, and $[001]_{(\mathrm{Nb}, \mathrm{Zr})} / /[100]_{\mathrm{ZrNi}}$. We have confirmed the existence of reversible endothermic peaks at approximately $1380 \mathrm{~K}$ and exothermic peaks at approximately $1300 \mathrm{~K}$ in the DTA heating and cooling curves, respectively. It has been reported that near-equiatomic $\mathrm{ZrPd}$ alloys undergo martensitic transformation from the B2 to B33 structures. ${ }^{16)}$ Therefore, we can assume that the $\mathrm{ZrNi}$ alloys as well as $\mathrm{ZrPd}$ alloys undergo martensitic transformation from the B2 to B33 structures. The lattice correspondence between the B2 parent and B33 martensitic phases is deduced as follows by considering the lattice parameters of both the structures: $[001]_{\mathrm{B} 2} / /[100]_{\mathrm{B} 33}$, $(110)_{\mathrm{B} 2} / /(010)_{\mathrm{B} 33}$, and $(1 \overline{1} 0)_{\mathrm{B} 2} / /(001)_{\mathrm{B} 33}$. The orientation relationship between the bcc- $(\mathrm{Nb}, \mathrm{Zr})$ phase and the $\mathrm{B} 2$ parent phase of $\mathrm{ZrNi}$ alloy is expressed as follows: $[001]_{(\mathrm{Nb}, \mathrm{Zr})} / /[001]_{\mathrm{B} 2-\mathrm{ZrNi}}, \quad(110)_{(\mathrm{Nb}, \mathrm{Zr})} / /(110)_{\mathrm{B} 2-\mathrm{ZrNi}}, \quad$ and $(1 \overline{10})_{(\mathrm{Nb}, \mathrm{Zr})} / /(\overline{1} 10)_{\mathrm{B} 2-\mathrm{ZrNi}}$, that is, they satisfy the cube-oncube relationship.

The orientation relationships of the eutectic structure in the four niobium-bearing alloys are summarized in Table 2. These observations provide that the eutectic structures in the $\mathrm{Nb}_{20} \mathrm{Ti}_{40} \mathrm{Ni}_{40}, \mathrm{Nb}_{13} \mathrm{Zr}_{43} \mathrm{Ni}_{44}$, and $\mathrm{Nb}_{25} \mathrm{Zr}_{35} \mathrm{Co}_{40}$ alloys possess the cube-on-cube relationship, while that in the $\mathrm{Nb}_{30} \mathrm{Ti}_{35} \mathrm{Co}_{35}$ alloy possesses a unique orientation relationship, i.e., $[\overline{2} 21]_{(\mathrm{Nb}, \mathrm{Ti})} / /[001]_{\mathrm{TiCo}}$ and $(110)_{(\mathrm{Nb}, \mathrm{Ti})} / /(110)_{\mathrm{TiCo}}$.

Onda et al. have investigated the cube-on-cube interface in the $\mathrm{Nb}_{20} \mathrm{Ti}_{40} \mathrm{Ni}_{40}$ alloy by using HRTEM observations and Ballman's O-lattice theory. ${ }^{9)}$ There exist misfit dislocations of $\boldsymbol{b}=1 / 2[\overline{1} 11]_{\mathrm{TiNi}}$ or $1 / 2[1 \overline{1} 1]_{\mathrm{TiNi}}$ with regular spacings of approximately $2.6 \mathrm{~nm}$ in the B2-TiNi phase. Since we also
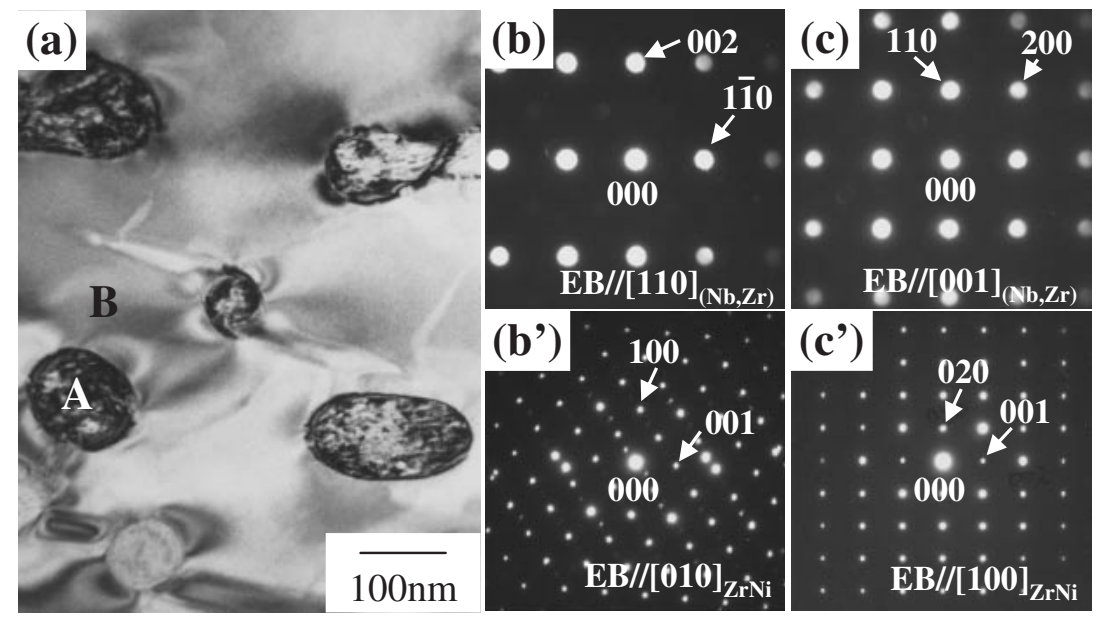

Fig. 7 (a) A bright field image and the corresponding electron diffraction patterns of (b) and (c) the area A, and (b') and (c') the matrix region $\mathrm{B}$ of the $\mathrm{Nb}_{13} \mathrm{Zr}_{43} \mathrm{Ni}_{44}$ alloy, respectively. 
Table 2 Orientation relationship between the two phases of the eutectic structure in the four niobium-bearing alloys.

\begin{tabular}{|c|c|c|c|c|}
\hline & $\mathrm{Nb}_{20} \mathrm{Ti}_{40} \mathrm{Ni}_{40}$ & $\mathrm{Nb}_{30} \mathrm{Ti}_{35} \mathrm{Co}_{35}$ & $\mathrm{Nb}_{13} \mathrm{Zr}_{43} \mathrm{Ni}_{44}$ & $\mathrm{Nb}_{25} \mathrm{Zr}_{35} \mathrm{Co}_{40}$ \\
\hline $\begin{array}{l}\text { Orientation } \\
\text { relationship of the } \\
\text { eutectic structure }\end{array}$ & $\begin{array}{l}{[001]_{(\mathrm{Nb}, \mathrm{Ti})} / /[001]_{\mathrm{TiNi}}} \\
(100)_{(\mathrm{Nb}, \mathrm{Ti})} / /(100)_{\mathrm{TiNi}} \\
(010)_{(\mathrm{Nb}, \mathrm{Ti})} / /(010)_{\mathrm{TiNi}}\end{array}$ & $\begin{array}{l}{[\overline{2} 21]_{(\mathrm{Nb}, \mathrm{Ti})} / /[001]_{\mathrm{TiCo}}} \\
(110)_{(\mathrm{Nb}, \mathrm{Ti})} / /(110)_{\mathrm{TiCo}}\end{array}$ & $\begin{array}{l}{[001]_{(\mathrm{Nb}, \mathrm{Zr})} / /[100]_{\mathrm{B} 33-\mathrm{ZrNi}} / /[001]_{\mathrm{B} 2-\mathrm{ZrNi}}} \\
(110)_{(\mathrm{Nb}, \mathrm{Zr})} / /(010)_{\mathrm{B} 33-\mathrm{ZrNi}} / /(110)_{\mathrm{B} 2-\mathrm{ZrNi}} \\
(1 \overline{1} 0)_{(\mathrm{Nb}, \mathrm{Zr})} / /(001)_{\mathrm{B} 33-\mathrm{ZrNi}} / /(1 \overline{1} 0)_{\mathrm{B} 2-\mathrm{ZrNi}}\end{array}$ & $\begin{array}{l}{[001]_{(\mathrm{Nb}, \mathrm{Zr})} / /[001]_{\mathrm{ZrCo}}} \\
(100)_{(\mathrm{Nb}, \mathrm{Zr})} / /(100)_{\mathrm{ZrCo}} \\
(010)_{(\mathrm{Nb}, \mathrm{Zr})} / /(010)_{\mathrm{ZrCo}}\end{array}$ \\
\hline
\end{tabular}
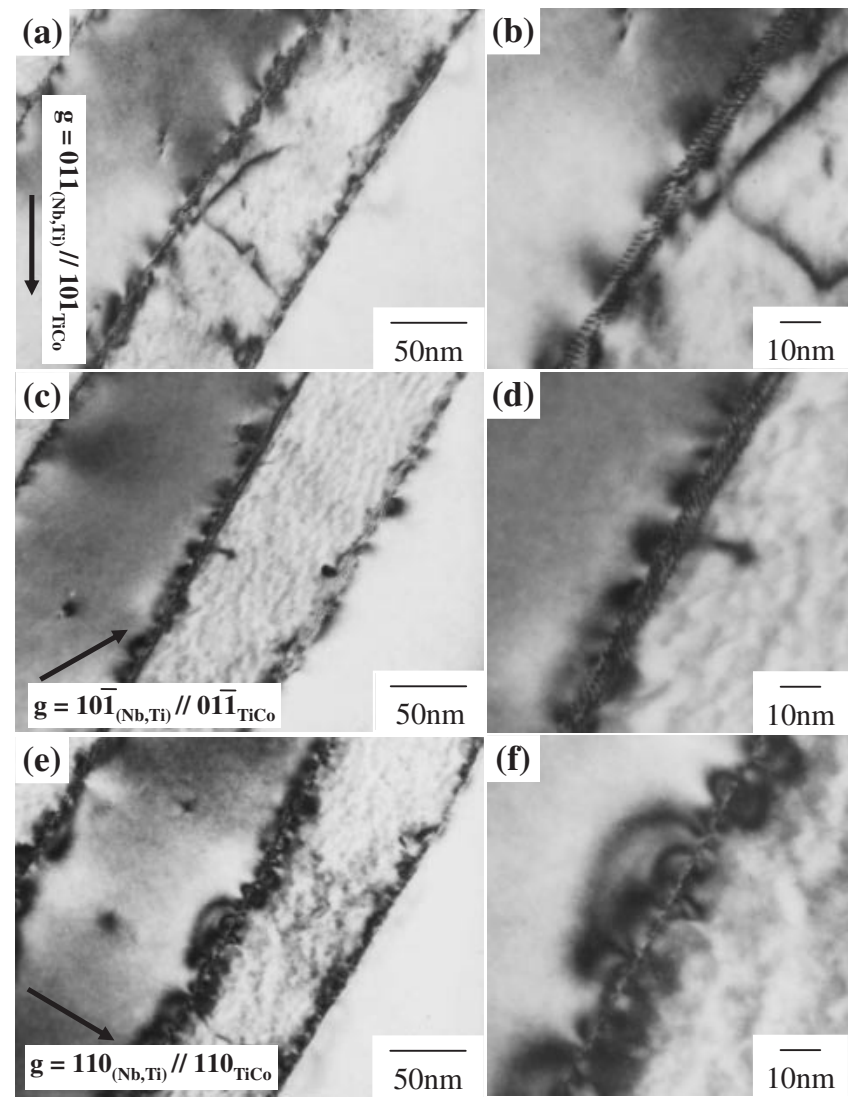

Fig. 8 (a), (c), and (e) Bright field images of the eutectic interface in the $\mathrm{Nb}_{30} \mathrm{Ti}_{35} \mathrm{Co}_{35}$ alloy, obtained for $\boldsymbol{g}=011_{(\mathrm{Nb}, \mathrm{Ti})} / / 101_{\mathrm{TiCo}}$ $10 \overline{1}_{(\mathrm{Nb}, \mathrm{Ti})} / / 01 \overline{1}_{\mathrm{TiCo}}$ and $110_{(\mathrm{Nb}, \mathrm{Ti})} / / 110_{\mathrm{TiCo}}$, respectively. (b), (d), and (f) Enlarged micrographs of the eutectic interface in (a), (c), and (e), respectively.

obtain the same results by the HRTEM observations, although we do not reproduce the micrograph here, only the unique eutectic interface in the $\mathrm{Nb}_{30} \mathrm{Ti}_{35} \mathrm{Co}_{35}$ alloy is discussed hereafter. Figure 8 shows the bright field images obtained from the $[\overline{1} 1 \overline{1}]_{(\mathrm{Nb}, \mathrm{Ti})} / /[\overline{1} 11]_{\mathrm{TiCo}}$ direction of the eutectic interface in the $\mathrm{Nb}_{30} \mathrm{Ti}_{35} \mathrm{Co}_{35}$ alloy. This direction corresponds to a unique condition in which the eutectic interface is in the edge-on state, observed from the low index zone axis of both the phases, as described in Figs. 5 and 6. In case of $\boldsymbol{g}=011_{(\mathrm{Nb}, \mathrm{Ti})} / / 101_{\mathrm{TiCo}}$ and $10 \overline{1}_{(\mathrm{Nb}, \mathrm{Ti})} / / 01 \overline{1}_{\mathrm{TiCo}}$, the periodic contrasts due to the misfit dislocations with the spacings of 1.5 to $1.8 \mathrm{~nm}$ are observed, as shown in Figs. 8(a) to $8(\mathrm{~d})$. On the other hand, when $\boldsymbol{g}$ is $110_{(\mathrm{Nb}, \mathrm{Ti})} / / 110_{\mathrm{TiCo}}$, no contrast is observed, as shown in Figs. 8(e) and 8(f). The two-dimensional lattice image of the eutectic interface from the $[\overline{1} 1 \overline{1}]_{(\mathrm{Nb}, \mathrm{Ti})} / /[\overline{1} 11]_{\mathrm{TiCo}}$ zone axis is presented in Fig. 9. The eutectic interface is almost parallel to the (110) plane of both the phases. We observe the extra half planes of $(101)_{\mathrm{TiCo}}$ on the eutectic interface, as indicated by the arrows. The

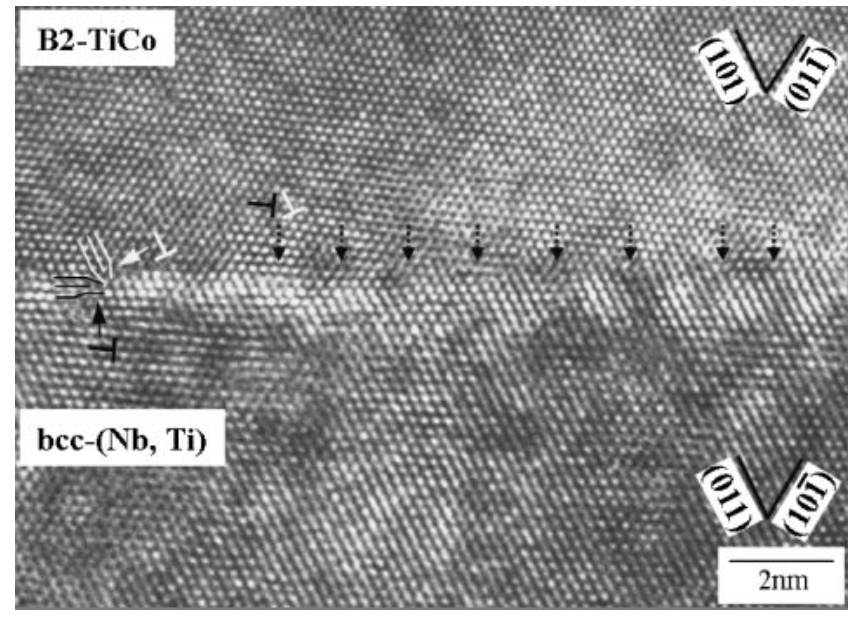

Fig. 9 Two-dimensional lattice image of the eutectic interface in the $\mathrm{Nb}_{30} \mathrm{Ti}_{35} \mathrm{Co}_{35}$ alloy, obtained from the $[\overline{1} 1 \overline{1}]_{(\mathrm{Nb}, \mathrm{Ti})} / /[\overline{1} 11]_{\mathrm{TiCo}}$ zone axis.

spacing between the $(101)_{\text {TiCo }}$ plane is of the order of 7-12 layers. This is consistent with the periodic contrasts shown in Fig. 8. In addition to the $(101)_{\text {TiCo }}$ plane, we can also identify the extra half planes of $(110)_{\text {TiCo }}$ along the eutectic interface. Therefore, it is confirmed that the two types of misfit dislocations are coupled and arranged along the eutectic interface. The complex strain contrast along the interface is probably due to the two types of misfit dislocations. The characterizations such as determination of the Burgers vector of these dislocations have not yet been completed. This analysis is now in progress and will be reported in due course.

Final comments concern about the relationship between the hydrogen permeability and the interface structure. The hydrogen permeability of the $\mathrm{Nb}$-Ti-Ni alloy increases with the volume fraction of the primary $(\mathrm{Nb}, \mathrm{Ti})$ phase. ${ }^{4,5)}$ On the other hand, the Nb-Ti-Co alloy with the eutectic composition possesses the highest hydrogen permeability among all the Nb-Ti-Co ternary alloys. ${ }^{6)}$ This indicates that hydrogen permeability depends on the alloy systems and their compositions. On the basis of the present microstructural observations, the crystal, macro-, and micro-structures of the eutectic $\mathrm{Nb}-\mathrm{Ti}-\mathrm{Ni}$ alloy are similar to those of the eutectic Nb-Ti-Co alloy. However, the orientation relationship between both the alloys and their interface microstructures are quite different. These facts suggest that the hydrogen permeation is probably influenced by the interface microstructure.

\section{Conclusions}

The morphology and crystallography of the eutectic structures in several niobium-bearing hydrogen permeation 
alloys such as $\mathrm{Nb}_{20} \mathrm{Ti}_{40} \mathrm{Ni}_{40}, \mathrm{Nb}_{30} \mathrm{Ti}_{35} \mathrm{Co}_{35}, \mathrm{Nb}_{13} \mathrm{Zr}_{43} \mathrm{Ni}_{44}$, and $\mathrm{Nb}_{25} \mathrm{Zr}_{35} \mathrm{Co}_{40}$ have been investigated by means of transmission electron microscopy. The atomic arrangements at the eutectic interface are also discussed on the basis of high-resolution observations. The obtained results are summarized as follows.

(1) The $\mathrm{Nb}_{20} \mathrm{Ti}_{40} \mathrm{Ni}_{40}, \mathrm{Nb}_{30} \mathrm{Ti}_{35} \mathrm{Co}_{35}$, and $\mathrm{Nb}_{25} \mathrm{Zr}_{35} \mathrm{Co}_{40}$ alloys have eutectic structures consisting of fine lamellar morphology with $\mathrm{Nb}$-based bcc and B2 intermetalic phases. The $\mathrm{Nb}_{13} \mathrm{Zr}_{43} \mathrm{Ni}_{44}$ alloy possesses a eutectic structure consisting of rod-shaped bcc-( $\mathrm{Nb}$, $\mathrm{Zr}$ ) and B33-ZrNi phases, which displacively transforms from the $\mathrm{B} 2$ high-temperature phase.

(2) The eutectic structure in the $\mathrm{Nb}_{20} \mathrm{Ti}_{40} \mathrm{Ni}_{40}$ and $\mathrm{Nb}_{25} \mathrm{Zr}_{35} \mathrm{Co}_{40}$ alloys exhibits a cube-on-cube orientation relationship between the bcc and the B2 phases. The eutectic structure in the $\mathrm{Nb}_{13} \mathrm{Zr}_{43} \mathrm{Ni}_{44}$ also exhibits the cube-on-cube orientation relationship by considering the lattice correspondence between the B2 and the B33 structures. On the other hand, a unique orientation relationship is found out in the $\mathrm{Nb}_{30}$ $\mathrm{Ti}_{35} \mathrm{Co}_{35}$ alloy, as follows: $(110)_{(\mathrm{Nb}, \mathrm{Ti})} / /(110)_{\mathrm{TiCo}}$ and $[\overline{2} 21]_{(\mathrm{Nb}, \mathrm{Ti})} / /[001]_{\mathrm{TiCo}}$.

(3) The strain contrast along the interface in the $\mathrm{Nb}_{30}$ $\mathrm{Ti}_{35} \mathrm{Co}_{35}$ alloy is more complex as compared to that in the $\mathrm{Nb}_{20} \mathrm{Ti}_{40} \mathrm{Ni}_{40}$ alloy. This is due to the two types of misfit dislocations coupled and arranged along the eutectic interface.

\section{Acknowledgements}

This study was supported by a "Grant-in-Aid for Scientific Research (B)" from the Japanese Society for the Promotion of Science (JSPS)" and "Grant-in-Aid for Young Scientists (B)" of the Ministry of Education, Culture, Sports, Science and Technology (MEXT), Japan. The authors would like to express their sincere appreciation to Prof. R. Tomoshige and Dr. S. Ii of Sojo University for their support in conducting the HRTEM experiments.

\section{REFERENCES}

1) C. Nishimura, M. Komaki and M. Amano: Mater. Trans., JIM 32 (1991) 501-507.

2) R. E. Buxbaum and T. L. Marker: J. Membrane Sci. 85 (1993) 29-38.

3) T. Ozaki, Y. Zhang, M. Komaki and C. Nishimura: Int. J. Hydrogen Energy 28 (2003) 1229-1235.

4) K. Hashi, K. Ishikawa, T. Matsuda and K. Aoki: J. Alloys Compd. 368 (2004) 215-220.

5) K. Hashi, K. Ishikawa, T. Matsuda and K. Aoki: Mater. Trans. 46 (2005) 1026-1031.

6) K. Hashi, K. Ishikawa, T. Matsuda and K. Aoki: J. Alloys Compd. 425 (2006) 284-290.

7) T. Takano, K. Ishikawa, T. Matsuda and K. Aoki: Mater. Trans. 45 (2004) 3360-3362.

8) K. Ishikawa T. Takano, T. Matsuda and K. Aoki: Appl. Phys. Lett. 87 (2005) 081906-1-081906-3.

9) T. Onda, M. Piao, Y. Bando, H. Ichinose and K. Otsuka: Mater. Trans., JIM 36 (1995) 23-29.

10) K. Kishida, Y. Yamaguchi, K. Tanaka, H. Inui, S. Tokui, K. Ishikawa and K. Aoki: Intermetallics. 16 (2008) 88-95.

11) K. Otsuka and X. Ren: Prog. Mater. Sci. 50 (2005) 511-678.

12) M. Piao, S. Miyazaki, K. Otsuka and N. Nishida: Mater. Trans., JIM 33 (1992) 337-345.

13) M. E. Kirkpatrick, D. M. Bailey and J. F. Smith: Acta Cryst. 15 (1962) 252-255.

14) A. Hellawell: Met. Mater. 1 (1967) 361-368.

15) H. E. Cline and J. L. Walter: Metall. Trans. 1 (1970) 2907-2917.

16) L. A. Bendersky, J. K. Stalick, R. Portier and R. M. Waterstrat: J. Alloys Compd. 236 (1996) 19-25. 